\title{
Prevalence and risk factors for cryptosporidiosis: a global, emerging, neglected zoonosis
}

\author{
Pwaveno Huladeino Bamaiyi ${ }^{1}$, Nur Eliyana Mohd Redhuan \\ Faculty of Veterinary Medicine, Universiti Malaysia Kelantan, Kelantan 16100, Malaysia
}

\begin{abstract}
Background: Cryptosporidiosis is a zoonotic disease caused by the important parasitic diarrheal agent Cryptosporidium spp. Cryptosporidiosis occurs in all classes of animals and man with a rapidly expanding host range and increased importance since the occurrence of human immunodeficiency virus/acquired immunodeficiency syndrome in man.

Objectives: To review the global picture of cryptosporidiosis in man and animals with emphasis on prevalence and risk factors.

Methods: Current relevant literature on cryptosporidiosis was reviewed.

Results: Cryptosporidiosis is widely distributed and the risk factors vary from one region to another with hygiene and immune status as important risk factors.

Conclusions: Cryptosporidium spp. associated mortality has not only been reported in immune-compromised patients, but also in immune-competent patients. Yet in many countries not much attention is paid to the control and prevention of this infection in animals and man. The neglect of this disease despite the serious threat it poses to animals, their husbandry, and humans, has led the World Health Organization to list it among globally neglected diseases. To control and prevent this infection more effort needs to be directed at controlling the risk factors of the infection in man and animals.
\end{abstract}

Keywords: Human and animal husbandry, cryptosporidiosis, neglected zoonosis

Cryptosporidiosis is a parasitic zoonotic disease affecting all terrestrial and most aquatic animals caused by 26 validated species (18 other species are not yet considered validated) of the genus Cryptosporidium. They are obligate intracellular parasites of man and animals on all continents except Antarctica. Cryptosporidiosis ranks 5th among the 24 most important food borne parasites globally [1-9]. There are 40 genotypes that have not yet been classified [7, 9]. Cryptosporidium species (spp.) are considered one of the most important parasitic diarrheal agents globally [10]. The disease usually manifests as a self-limiting diarrhea in immunecompetent individuals, and as a progressively lifethreatening diarrhea in immune-compromised patients such as those with human immunodeficiency virus infection/acquired immunodeficiency syndrome (HIV/AIDS), the young and the elderly; individuals

Correspondence to: Pwaveno Huladeino Bamaiyi, ${ }^{1}$ Present address: Department of Public Health, School of Allied Health Sciences, Kampala International University, Uganda.

E-mail: pwaveno.bamaiyi@kiu.ac.ug undergoing cancer chemotherapy, and any other condition that compromises the immune system including simple malnutrition. The infection is increasingly becoming associated with travel [11]. The size of the inoculum does not have any apparent effect on the severity and duration of disease. As few as 10 oocysts are capable of causing severe infection with only partial immunity acquired after 2 weeks recovery from primary infection and rechallenge with the same organism [12].

A specific treatment has not yet been developed for cryptosporidiosis in man and animals, but nitazoxanide (Alinia) has shown encouraging results [13] and has been approved by the U.S. FDA for the treatment of cryptosporidiosis. Nitazoxanide has as yet not become generally available worldwide. However, effects of nitazoxanide in HIV/AIDS or immune-deficient patients are not any better than a placebo for treating cryptosporidiosis [9]. Paromomycin and other antibiotics such as spiramycin have been used, but their efficacy is in doubt [14]. Fortunately, cryptosporidiosis is a self-limited disease in healthy adults, and can be expected to subside with conservative measures and dietary manipulation. 
Despite the seemingly ubiquitous nature of cryptosporidiosis, sufficient attention has not been paid to it, prompting the WHO in 2004 to list it among globally "neglected diseases" which have a common link with poverty in most developing countries [15]. It can be deadly in malnourished or immune compromised individuals; particularly in underdeveloped countries with an HIV/AIDS endemic not able to manage a severely afflicted patient with sophisticated nutritional support until treating the primary underlying problem takes effect. This article highlights the global distribution, prevalence and risk factors of this ubiquitous parasite with special reference to Asia, and presents its neglected status around the world.

Cryptosporidium spp. belong to the Kingdom of Protozoa; phylum Apicomplexa; class Conoidasida; order Eucoccidiorida; Family Cryptosporidiidae, and Genus Cryptosporidium [16]. In 1895, Clarke reported parasitic forms that he described as "swarm spores lying upon the gastric epithelium of mice" [17], which may have been Cryptosporidium muris, which were later described by the renowned American parasitologist, E. E. Tyzzer as "a sporozoan found in the peptic glands of the common mouse" in 1907 [18]. Today, several species of Cryptosporidium have been described. They include $C$. hominis, $C$. parvum, C.felis, C. andersoni, C. suis, C. canis, $C$. meleagridis, C. molnari, C. scophthalmi, $C$. scrofarum, C. bovis, and C. xiaoi, infecting most species of animals and man [10,19-22]. One of the latest species with probable worldwide distribution was initially named $C$. cervine genotype and infrequently as cervid, W4, or genotype 3 . It is now recognized as a distinct species C. ubiquitum [23]. The advent of molecular biology and its methods has helped to identify and classify many species of Cryptosporidium spp., a rapid progress from the initial single species identified in 1907. The complete list of validated Cryptosporidium spp. based on morphological, biological, and molecular data of 2014 is shown in Table 1.

Table 1. Validated species of Cryptosporidium

\begin{tabular}{|c|c|c|c|c|}
\hline S/No. & $\begin{array}{l}\text { Species of } \\
\text { Cryptosporidium }\end{array}$ & Major hosts & Zoonotic status & Reference \\
\hline 1. & C. andersoni & Cattle & Yes & {$[24]$} \\
\hline 2. & C. baileyi & Birds & No & {$[25,26]$} \\
\hline 3. & C. bovis & Cattle & Yes & [27] \\
\hline 4. & C. canis & Dogs & Yes & [28] \\
\hline 5. & C. cuniculus & Rabbits & Yes & {$[29,30]$} \\
\hline 6. & C. erinacei & Hedgehogs and horses & Yes & [31] \\
\hline 7. & C. fayeri & Marsupials & Yes & {$[32]$} \\
\hline 8. & C.felis & Cats & Yes & {$[33]$} \\
\hline 9. & C. fragile & Toads & No & {$[34]$} \\
\hline 10. & C. galli & Birds & No & {$[35]$} \\
\hline 11. & C. hominis & Humans & Most common species in humans & {$[36]$} \\
\hline 12. & C. macropodum & Marsupials & No & {$[37]$} \\
\hline 13. & C. meleagridis & Humans and birds & Yes & {$[4,38]$} \\
\hline 14. & C. molnari & Fish & No & {$[39,40]$} \\
\hline 15. & C. muris & Rodents & Yes & [41] \\
\hline 16. & C. parvum & Ruminants & Yes & {$[42]$} \\
\hline 17. & C. ryanae & Cattle & No & [43] \\
\hline 18. & C. scrofarum & Pigs & Yes & [44] \\
\hline 19. & C. serpentis & Snakes and lizards & No & {$[45,46]$} \\
\hline 20. & C. suis & Pigs & Yes & [47] \\
\hline 21. & C. tyzzeri & Rodents & Yes & [48] \\
\hline 22. & C. ubiquitum & Primates, ruminants, and rodents & Yes & [49] \\
\hline 23 & C. varanii & Lizards & No & {$[50]$} \\
\hline 24. & C. viatorum & Humans & Less common species in humans & {$[51]$} \\
\hline 25. & C. wrairi & Guinea pigs & No & {$[52]$} \\
\hline 26. & C. xiaoi & Sheep and goats & Yes & {$[53]$} \\
\hline
\end{tabular}


The following 18 species proposed by some researchers have not been validated: $C$. crotali, $C$. vulpis, C. baikalika, C. ctenosauris, C. lampropeltis, C. amievae, C. agni, C. anserinum, C. rhesi, C. garnhami, C. nasorum, C. enteriditis, $C$. villithecum, C. curyi, C. saurophilum, C. scophthalmi, C. pestis, and $C$. ducismarci [9].

The life-cycle of Cryptosporidium spp. is mostly similar to that of other coccidia (e.g. Eimeria and Isospora) affecting mammals and divided into 6 stages:

1. Excystation, which involves the release of infective sporozoites;

2. Merogony, which is the asexual multiplication that takes place within the cells of the host;

3. Gametogony, which is the formation of microgametes and macrogametes;

4. Fertilization, which is the fusion of the microgametes and macrogametes;

5. Oocyst wall formation, which is needed to form an environmentally resistant stage responsible for transmission of infection from one host to another; and

6. Sporogony, which is responsible for the formation of infective sporozoites within the oocyst wall.

An important distinction in the life-cycle of Cryptosporidium spp. is that each intracellular stage of Cryptosporidium spp. resides within a parasitophorous vacuole located in the microvillous region of the host cell, but that of Eimeria and Isospora are usually found in parasitophorous vacuoles perinuclear within the host cells. The oocysts of Cryptosporidium spp. undergo sporogony within the host cells releasing already infective sporozoites in the feces, whereas oocysts of other coccidia need optimum environmental conditions to sporulate and become infective [54]. The sporulated oocysts of Cryptosporidium spp. containing 4 sporozoites are excreted in the feces and perhaps other routes such as respiratory secretions especially in birds and children that may suffer from respiratory cryptosporidiosis $[55,56]$.

\section{Human cryptosporidiosis}

Accurate data on human cases of cryptosporidiosis are lacking from many countries where it is underdiagnosed and underreported. In recent years cryptosporidiosis has been found to not only affect the gastrointestinal tract, but also cause respiratory symptoms in man [6]. Probably the most famous outbreak of cryptosporidiosis was the outbreak in Milwaukee, USA, in 1993 that affected about 403,000 people, showing symptoms such as vomiting, watery diarrhea, stomach cramps, and fever [57]. The water treatment plant in Milwaukee was implicated in the outbreak in which there was a 100 fold increase in isolation of Cryptosporidium spp. compared with other enteric pathogens with a median duration of, supportive treatment, and an illness of 9 (range, 1-55) days. The Milwaukee outbreak could have been averted by possibly reducing delays in identifying and publicizing the known risk [58]. Different studies have shown the limitation of normal filters and standard water processing procedures in controlling Cryptosporidium spp. because of their minute size and high resistance to normal methods and agents to purify water for human consumption [59-62]. Outbreaks in health facilities, such as hospitals, have also been reported [63].

\section{Prevalence and risk factors Africa}

Young children are in some of the most high risk groups for cryptosporidiosis in various African countries. The overall prevalence of cryptosporidiosis in children aged 0 to 15 years in the arid region of Borno State, Nigeria was reported to be $42.9 \%$ [1]. The children were found to be exposed to the infection through unhygienic environments and use of contaminated water facilities. It is generally known that undernourished and HIV seropositive children are more likely to have cryptosporidiosis than wellnourished normal host children. However in Jos, Nigeria; it was found that none of a group of HIV positive and undernourished children excreted oocysts in their faeces. However, $3.8 \%$ of children aged 0-5 years in a control group, consisting of HIV seronegative children, excreted oocysts in their stool [64]. This finding is important and suggests that children are easily infected by oocysts irrespective of their HIV status, and may remain relatively asymptomatic. The public health implications of this infection are further complicated by possible contamination of vegetables and other food items by oocysts. This can have serious implications for a country with a considerable number of immunocompromised HIV/AIDS patients and others with suppressed immunity [65]. The presence of various parasites in vegetables is a problem 
worldwide [66]. Socioenvironmental predictors of cryptosporidiosis in two communities in Nigeria include: presence of younger children in community (odds ratio $(\mathrm{OR})=1.889, P<0.0001,95 \%$ confidence interval $(\mathrm{CI})=1.568-2.274)$, presence of diarrhea $(\mathrm{OR}=2.66, P<0.0001,95 \% \mathrm{CI}=1.733-4.100)$, younger age group $(\mathrm{OR}=1.283, P=0.004,95 \% \mathrm{CI}=$ $1.085-1.520)$, married status $(\mathrm{OR}=2.463, P=0.028$, $95 \% \mathrm{CI}=1.100-5.513)$, lack of formal education $(\mathrm{OR}=2.993, P<0.0001,95 \% \mathrm{CI}=1.872-4.786)$, and farming occupation $(\mathrm{OR}=1.392, P=0.002$, $95 \% \mathrm{CI}=1.135-1.703)$. Regular hand washing $(\mathrm{OR}=0.399, P<0.0001,95 \% \mathrm{CI}=0.283-0.535)$ was protective [67].

A study of 442 stool samples from children aged $<5$ years found a prevalence of $12.2 \%$ from 4 provinces in South Africa. It included a first report from South Africa of a Cryptosporidium sp. rarely reported in humans, C. meleagridis. This implies a tendency towards expanding hosts by different species of this parasite [68].

In most African countries the high poverty level, coupled with relatively high HIV prevalence rates, has made cryptosporidiosis an important public health problem. Economic burdens and poor sanitary facilities have helped the infection to continue spreading among the population. This apparent neglect of attention to this important emerging zoonotic disease, suggests that microscopic diagnosis is often missed because technicians search first, and often only, for better known other diarrhea-causing parasites.

\section{Asia}

Cryptosporidiosis cases have been reported in Cambodia, Indonesia, Laos, Malaysia, Myanmar, the Philippines, Singapore, Thailand, and Vietnam. In Bangkok, among the Cryptosporidium spp. that have been isolated from HIV patients are C. parvum, $C$. hominis, C. meleagridis, C. canis, C. felis, C. muris, and $C$. parvum bovine genotype 5 [69, 70, 71]. However, in Malaysia, C. parvum were found to be rare in the past [72], but have become common recently being $84.3 \%$ of Cryptosporidium spp. isolates [73]. This may show that the parasite is adapting to infecting many more hosts or that diagnosis and identification technology is improving.

Cryptosporidiosis is widespread in Southeast Asia in both humans and animals [74]. For instance, in Thailand, a study revealed that $11 \%$ and $6 \%$ of river and ocean water collected from various locations in
Thailand were contaminated with Cryptosporidium spp. [75]. In a comparative study of water contamination in Malaysia and Thailand, it was shown that recreational water in Malaysia was more significantly contaminated with Cryptosporidium spp. oocysts than in Thailand [76]. A team of researchers from Kuala Lumpur National Zoo reported the presence of a coccidian parasite among birds. They postulated that the birds may appear asymptomatic and become vectors of Cryptosporidium spp. oocysts [77]. Viability and infectivity of Cryptosporidium spp. is retained after passage through an avian host and is quite resilient in the environment [78].

In India, a study found that both HIV and nonHIV patients attending a hospital had a prevalence of $38.60 \%$ and $2.52 \%$ respectively, showing a high prevalence in HIV patients [79]. Among the HIV patients $20.8 \%$ had an infection with Cryptosporidium. Cryptosporidiosis was also common in patients undergoing renal transplants. C. hominis, C. parvum, and mixed infections were detected in 50/71 (70.4\%), and this was associated with higher stool frequency and a watery stool. A high parasite loads, vomiting and nausea was more frequently associated with $C$. hominis than with $C$. parvum [80]. In the rural areas of Bangladesh, calf handlers showed a prevalence of $3.2 \%$ for Cryptosporidium spp. [81].

Cryptosporidiosis in Asia appears to be associated with urbanization and rapid increase of population. Water sources are insufficient and not well maintained and open to contamination by animals and birds [21].

\section{The Americas}

The importance of contaminated vegetables as a risk factor for cryptosporidiosis was demonstrated by a study in Costa Rica. It consisted of 640 samples from 8 different vegetables normally consumed raw. They were analyzed for the presence of Cryptosporidium oocysts, fecal coliforms, and Escherichia coli. The study found that whereas Cryptosporidium oocysts were absent in cabbage, they were found in $5.0 \%$ (4 samples) of cilantro (coriander) leaves, $8.7 \%$ ( 7 samples), of cilantro roots, and $2.5 \%$ ( 2 samples) of lettuce. A $1.2 \%$ contamination rate was detected in samples of other vegetables (radish, tomato, cucumbers, and carrot) with a greater percentage of oocysts found during the rainy season; but only in cilantro leaves and lettuce. Positive linear correlation was established between the presence of 
oocysts of Cryptosporidium and fecal coliforms and E. coli [82]. This is a major concern considering the increasing number of immune-compromised individuals in this developing country and the neglect of the threat of cryptosporidiosis in food used for human consumption. Some other food items like milk may also be infected with viable oocysts, but the simple process of pasteurization of milk has long been shown to be sufficient to inactivate oocysts [83]. The process of cooking food and boiling water has long been shown to destroy oocysts and prevent infection [84].

The USA continued to battle elevated incidence rates for cryptosporidiosis nationally with a total of 9,313 and 8,008 cases reported in 2011 and 2012 respectively; with children aged 1-4 years having the highest number reported cases (6.6 per 100,000 population). Next most frequently infected were the elderly, aged $\geq 80$ years ( 3.4 per 100,000 ), and $75-79$ years $(3.3$ per 100,000$)$; with women having higher cryptosporidiosis rates in both age groups than men. However, rates were higher among boys $<15$ years old and higher among women and girls $\geq 15$ years old [41]. Sex is usually not significantly associated with cryptosporidiosis infection [85-87].

People in Brazil and other countries in South America suffer from cryptosporidiosis; especially children and the immunocompromised. Children with diarrheal episodes because of Cryptosporidia continued to suffer from excessive and protracted diarrheal illness for about 2 years. Children in Brazil, who had no Cryptosporidium induced diarrhea soon after birth, did not show further increased diarrheal illnesses [88]. Cryptosporidium infection was found to cause stunted growth of children. Presumably because of the protracted periods of persistent diarrhea. This is particularly important because of the lack or poor efficacy of currently available drugs. Children in densely populated or crowded suburbs were at greater risk of symptomatic infection. It was found that Cryptosporidium oocysts were identified in $7.4 \%$ and more frequently in children with consistent diarrhea $(16.5 \%)$, than in those with acute $(8.4 \%)$ or no $(4.0 \%)$ diarrhea $(P<0.001)$ [89].

\section{Europe}

According to the European Centre for Disease Prevention and Control (ECDC), there was an unprecedented increase in cryptosporidiosis in the United Kingdom, The Netherlands, and Germany in late summer/autumn of 2012. In the same year, 2173 cases of cryptosporidiosis were reported in England and Wales, which was 1.5 fold higher than in the previous year and is the greatest since 2003 . The most commonly isolated Cryptosporidium sp. was $C$. hominis. Although the number of cases reported in Germany is lower than in England, it was a 1.6 fold increased since 2007 [90].

The suggested reasons for this increase include climatic changes, such as heavy rainfall, contaminated drinking water, and better reporting. Nevertheless, there was no direct evidence of secondary transmission from parents to children. Moreover, specific causes of Cryptosporidium spp. infection were not identified, despite case interviews.

The prevalence of Cryptosporidia in Northern Spain was on average $1 \%$ in children and $3 \%$ in cattle [91]. The virtually simultaneous presentation of infection in both humans and animals gives credence to the assertion of this being a zoonotic disease.

In Ostersund, Sweden in November 2010, about $45 \%$ of the inhabitants were affected by cryptosporidiosis caused by $C$. hominis from contaminated public water supply [36]; similar to the Milwaukee outbreak of 1993 in the USA. The outbreak was characterized by rapid onset of symptoms and high attack rate, especially among young and middle aged persons. Identified risk factors where: family member, amount of water consumed daily, and gluten intolerance. The exact amount of pathogen needed to trigger a water borne infection is still unknown, but is likely to be low.

\section{Australia}

In Western Australia in 2012, there were 18 notified cases of human cryptosporidiosis through contamination of a swimming pool with viable oocysts [22].

In 2001, an outbreak of cryptosporidiosis in Northern Tasmania was highly associated with human exposure to cattle. Within one month, there were 48 cases of cryptosporidiosis reported with high prevalence seen among people who attended an agricultural fair [92]. In New South Wales, 1141 people became infected with Cryptosporidium spp. in 2009 because of contaminated public swimming pools [93].

Prevalence rates of cryptosporidiosis in Australia are a major public health problem and higher than in other developed countries. Although cryptosporidiosis was also associated with rainfall, cases of it have been reported to occur in hot and dry areas like Brisbane. 
In rural areas, cases of cryptosporidiosis are related to a high density of cattle [94]. The most important Cryptosporidium spp. identified in humans in Australia include: C. hominis, C. parvum, $C$. meleagridis, C. fayeri, C. andersoni, and C. bovis [7].

\section{Animal cryptosporidiosis}

Cryptosporidiosis has been reported from different species of animals worldwide. These include fish, reptiles, mammals, and birds with varying prevalence rates and sometimes seasonal fluctuations. The economic impact of cryptosporidiosis in livestock is becoming clearer with more studies showing it has significant economic impact with clinical signs that may vary from symptomatic to deadly [95]. Cryptosporidiosis has been shown to have negative effects on animal live weights, growth rates, meat quality and dressing percentage in lamb [96]. Moreover, infection leads to economic losses resulting from retarded growth of animals, mortality of animals, and increase in labor and veterinary care assistance, even after the recovery of animals [95].

\section{Prevalence and risk factors Africa}

Cryptosporidiosis has been reported in birds in Zaria, Nigeria with a prevalence of $5.3 \%$ in wild birds, $6.6 \%$ in exotic birds, $9.5 \%$ in local birds, and an overall prevalence in birds of $7.4 \%$. The ease of contact with oocysts by kept birds. Scavenged feed was one of the main reasons given for the possible higher prevalence of oocysts [2]. Cryptosporidium spp. were found in water buffaloes in Egypt using modified Ziehl-Neelsen staining and DNA sequencing of the small subunit rRNA. C. parvum and C. ryanae were found the predominant species with $C$. ryanae being most prominent. This suggests that in water buffaloes this new species, $C$. ryanae may be more important than $C$. bovis and C. andersoni [97]. Cryptosporidium spp. infection has been reported in animals from different regions and countries in Africa with varying prevalence rates and risk to man. The widespread distribution of the infection in both domestic and wild animals is of public health concern and its presence in water bodies, such as rivers, ponds and other water sources used by both animals and humans implies that the infection can be easily spread [10, 98-101].

\section{Asia}

Iran

A study in Iran demonstrated the importance of considering cryptosporidiosis as a differential diagnosis in infections of lambs and goat kids by showing a significant infection of cryptosporidiosis according to age groups; with the highest rate of infection found in animals 1 month of age. Diarrheic fecal samples had a significantly higher prevalence than the nondiarrheic samples. Overall prevalence of cryptosporidium oocysts was $10.24 \%$ and $18.86 \%$ in lambs and kids respectively [102]. The importance of wild rats as reservoirs of C. parvum was shown in a study in Iran where $27.3 \%$ of rats were positive for $C$. parvum using nested polymerase chain reaction (PCR); highlighting the public health implications of this infection in areas where there is contact between humans and rats [103]. In another study, the prevalence of Cryptosporidium spp. in sheep in different regions of Iran was $11.3 \%$ with significant difference in prevalence based on age and sex [104].

\section{Malaysia}

In a study of cryptosporidiosis in Malaysia, a case fatality of $40 \%$ was reported in a dairy farm where inadequate nutrition and lack of hygiene were implicated in the occurrence [105]. Among domestic animals, dairy cattle are one of the most prone to cryptosporidiosis [19, 106, 107]. In another more recent study in Malaysia, a prevalence of $3.2 \%$ was reported for asymptomatic Cryptosporidium spp. infection in cattle with $C$. bovis and $C$. ryanae reported in 4 out of 6 farms studied [108].

\section{China}

The first description and report of $C$. andersoni in horses in 2015 was from China. This has expanded the host range for this species and showed possibility of cross transmission of this species between cattle and horses especially when grazed together [109]. In a study on avian cryptosporidiosis, 2579 fecal samples were collected from 21 prefectures in Henan, China. The overall infection rate was $10.6 \%(163 / 1542)$ in layer chickens (10 out of 17 farms), 3.4\% (16/473) in broilers (five out of 29 farms), and $16.3 \%(92 / 564)$ in Peking ducks (4 out of 8 farms), respectively. The highest prevalence rates were seen in 31-day-old to 60-day-old layer chickens (24.6\%) and 11-day-old to 30-day-old Peking ducks (40.3\%). C. baileyi and C. meleagridis were the species identified with 
C. baileyi being predominant [110]. This has zoonotic implications because of the closeness of man to poultry and because $C$. meleagridis is the third most common Cryptosporidium spp. parasite in humans [111]. Cryptosporidiosis is suspected to be endemic in dogs across China even though only few extensive studies had been conducted. From 84 fecal samples taken from cats, dogs and from waste water of zoo drainage channels, in a study in Shanghai, China, an infection rate of 7\% was reported [112]. From 545 fecal samples taken from yaks in nine different counties of central western region of China, the prevalence of Cryptosporidium spp. was $4.0 \%$ and sequence analysis of the small subunit rRNA (SSU rRNA) gene of the Cryptosporidium spp. isolates confirmed the species as $C$. parvum $(\mathrm{n}=12), C$. bovis $(\mathrm{n}=6), C$. ryanae $(\mathrm{n}=3)$, and $C$. ubiquitum $(\mathrm{n}=1)$. These findings may implicate yaks as possibly playing a role in the transmission of zoonotic cryptosporidiosis in China and shows the predominance of $C$. parvum in China over other species [113]. The relatively new species, $C$. xiaoi was the dominant species found in samples taken from 12 goat farms across 4 provinces (Guangdong, Hubei, Shandong, and Shanghai City) with a prevalence ranging from $2.9 \%$ to $25.0 \%$. Other species identified were $C$. parvum and $C$. ubiquitum with goat kids more susceptible than adult goats [114].

\section{Myanmar}

There is a dearth of literature on the epidemiology of cryptosporidiosis in Myanmar. However, a few studies conducted showed that it is widely distributed in animals where studied. The overall prevalence reported in cattle in the Mandalay region was 56 of 400 cattle. Calves under 6 months had a significantly higher risk of cryptosporidiosis $(\mathrm{OR}=2.27, \mathrm{CI}=1.11$ $4.66, P=0.02)$. Grazing $(\mathrm{OR}=3.78, \mathrm{CI}=2.35-6.06$, $P=<0.001)$ and drinking water from a pond or river $(\mathrm{OR}=0.25, \mathrm{CI}=0.16-0.37, P=<0.001)$ were significantly associated with the risk of Cryptosporidium spp. infection in cattle [115]. This study confirms already known risk factors for cryptosporidiosis as a life threatening infection in young animals with sporulated oocysts that can contaminate small and large bodies of water [116].

\section{India}

India reported varying prevalence of Cryptosporidium spp. infection in domestic and wild animals [117]. Cryptosporidium spp. infection was associated with hydrocephalus [118]. This raises the question of the possibility of vertical transmission, although some previous investigators have not agreed $[119,120]$. However, an experimental study in mice demonstrated vertical transmission of Cryptosporidium spp. infection [121]. In a study of prevalence and risk factors associated with young livestock in India, the overall prevalence was $16.2 \%$ of the animals studied with Cryptosporidium spp. infection prevalence of $16.3 \%$ in cattle calves, $24.2 \%$ in buffalo calves, $1.8 \%$ in lambs, $3.5 \%$ in kids, and $19.1 \%$ in piglets. Infection was found to be significantly associated with age, sex, season, and diarrhea [122].

\section{Pakistan}

There have been several reports of Cryptosporidium spp. infections, especially in Bovine spp., from different parts of Pakistan. A prevalence of $10.5 \%$ in cattle was reported from Lahore on dairy farms run by the Government. It is also higher than on military and private dairy farms. The highest prevalence was during the summer. A higher prevalence was detected using PCR than microscopy, but the difference was not significant [123]. The treatment of calves using azithromycin was effective, but using cotrimoxazole and kalvangi (Nigella sativa, also known as black cumin) was ineffective [124]. In another study in Lahore, overall, $25.6 \%$ calves were found to be shedding $C$. parvum with a prevalence of $27.2 \%$ in cows and $24 \%$ in buffalo calves [125]. In small ruminants, a prevalence of $18.7 \%$ in goats and $21.3 \%$ in sheep has been reported. It was more prevalent (40\%) in lambs. Among positive animals, $75 \%$ of goats and $71.9 \%$ of sheep were having diarrhea. In the same study, 200 water samples were collected for analysis and found $10.5 \%$ overall prevalence. Water samples contained $28 \%$ C. parvum oocysts in canal water, $8 \%$ in tap water, and $4 \%$ in underground water, whereas no oocyst was found in mineral water bottles, making it the safest source of water for human consumption [126].

\section{Japan}

Hedgehogs are popular pets in Japan. But they have been found to harbor two zoonotic Cryptosporidium spp.: C. parvum and C. erinacei (which are known as the hedgehog genotype). In the same study, Cryptosporidium horse genotype 
was identified in a four-toed hedgehog (Atelerix albiventris) and $C$. serpentis lizard genotype, in geckos (Teratoscincus scincus) by sequencing analysis of partial SSU rRNA and actin genes. This was the first report of Cryptosporidium spp. isolates in pet birds in Japan [127]. Murakoshi et al. [128] showed that $C$. parvum 1 (CSpV1), a member of the family Partitiviridae, was capable of infection by C. parvum.

\section{Thailand}

Cryptosporidiosis is widespread and associated with diarrhea among HIV/AIDS patients. In a study of 108 dairy cattle farms in the Nong Pho region of central Thailand, $31.5 \%$ of farms were contaminated with Cryptosporidium spp. [129]. To estimate the prevalence of cryptosporidiosis in water buffalo in northeast Thailand, 600 samples from 287 farms in 6 provinces were investigated using DMSO-modified acid-fast staining and PCR. Individual animal prevalence was $5.7 \%$ and herd level prevalence was $8.7 \%$ in provinces located around Sakhon Nakhon in the northern part of the region having the highest prevalence. Farms with more than 5 buffalo had a higher prevalence (30\%) compared to farms with 5 or less $(16.2 \%)$, with $C$. parvum making up $88.2 \%$ of infections while the remaining $11.2 \%$ of infections were from C. ryanae [130]. To determine the spread of the parasites in the Thailand, Koompapong et al. collected fecal samples from seagulls (Chroicocephalus brunnicephalus and Chroicocephalus ridibundus), domestic pigeons (Columba liviadomestica), dogs, and cats from different locations. The results showed $C$. meleagridis in pigeons, Cryptosporidium avian genotype III in seagulls, C. canis in dogs, and C. felis in cats. The prevalence was $2.1 \%(2 / 95)$ for dogs in a Temple and $2.5 \%(2 / 80)$ for cats. This was the first report of $C$. meleagridis in domestic pigeons and Cryptosporidium avian genotype III in seagulls [131]. Long-tailed macaques (Macaca fascicularis) that reside among human communities in Thailand and come into regular contact with man showed a low prevalence of 1\% for Cryptosporidium spp. monkey genotype. Although this prevalence is low in monkeys in Thailand, it portends risks of human infection because of frequent human contacts and the low number of oocysts require for human infection [132].

\section{Turkey}

Several workers have reported varying prevalence of cryptosporidiosis in Turkey. In one study of 307 calves, C. parvum was the only Cryptosporidium sp. found using nested PCR to amplify fragments of the Cryptosporidium SSU rRNA gene with a prevalence of $3.9 \%$ [133]. In the east and southeast of Turkey, using immunochromatographic rapid tests, the prevalence of Cryptosporidium spp. was $21.8 \%$ in diarrheic and healthy calves [134]. The first report of the various subtypes of C. parvum in Turkey revealed C. parvum IIa (12/13), IId (1/13) subtype family and IIaA15G2R1 (10/13), IIaA16G3R1 (2/13), IIdA15G1 (1/13) subtypes/subgenotypes were seen in cattle while $C$. parvum IIaA15G2R1 (9/10) and HaA16G3R1 (1/10) were determined in calves. C. parvum IIaA16G3R1 $(2 / 3)$ and IIdA15G1 (1/3) were determined in cows. The subtype family of $C$. parvum IIa (8/8) along with the $C$. parvum subtype IIaA15G2R1 (7/8) were regularly seen in diarrheic calves [135]. Various water sources investigated in Turkey, which could be sources of drinking water for humans and animals, revealed $5.2 \%$ prevalence for C. parvum [136].

\section{Middle East}

In the Middle East, Cryptosporidium spp. infection is known to be prevalent in domestic and wild animals. In a study in Iraq, the prevalence of Cryptosporidium spp. infection was $61 \%$ in camels and $56 \%$ in the camel breeders [137]. This raises again the important issue of cross transmission of this parasite from animals to humans and from humans to animals. Considering that the camel, known to be hardy against parasitic infections [138, 139], could have this high prevalence in both camels and humans caring for them, shows the hardiness of this protozoan parasite and its ability to adapt and survive in several different hosts.

\section{North America}

Cryptosporidiosis has been reported from the USA and Canada from different species of animals including ruminants, birds, marine, and wild animals. The widespread nature of Cryptosporidium spp. infecting animals in both developing and developed countries reveals the seeming ubiquitous nature of this parasite. The annual burden of illness attributed to Cryptosporidium spp. was 113,344 [140]. Lack of or limited subtyping tools make it difficult to determine the role of zoonotic transmission of 
Cryptosporidium chipmunk genotype I, but in a study of Cryptosporidium chipmunk genotype I isolates, it was shown to be genetically similar from humans and wild life, suggesting zoonotic transmission may play a role in human infections. Many other reports of cryptosporidiosis in North America are available [141-145].

\section{South America}

In a study in Chile, using Ziehl-Neelsen and auramine staining techniques, Cryptosporidium spp. infection was present in calves on milk farms with $57.9 \%$ of all the animals testing positive with the ZiehlNeelsen stain, while $55.6 \%$ of all the animals turned out positive in the auramine stain test. The McNemar test indicated no significant difference between both diagnostic techniques $(P>0.05)$. The kappa index showed proper concordance between tests $(\kappa=0.73)$ [146]. Colombia first reported Cryptosporidium spp. in cats in 2006 and the infection is considered wide spread in various animal species in Colombia [147]. There are several reports of cryptosporidiosis from this region using different methods [148-151].

\section{Europe}

Cryptosporidium spp. has been reported from different animals across Europe. Control in livestock farms have been very difficult; especially in dairy cattle farms, which are usually intensively managed. This makes the spread of the infection easy because of increased contact between animals and their droppings, which may contain viable oocysts [152]. A study in roe deer (Capreolus capreolus) in Galicia (northwest Spain) two species of Cryptosporidium spp. were identified (C. bovis and C. ryanae) with a prevalence of $4.2 \%$ and infection was more in juvenile than adult animals, but the difference was not significant. The mean intensity of infection ranged between 5 and 225 oocysts/g [153]. There are several reports of cryptosporidiosis from Europe [152, 154, 155], which should be consulted for detailed information.

\section{Australia}

The Australian livestock industry has been known to suffer from cryptosporidiosis caused by many genotypes that are undergoing ongoing study [7]. Different wild and domestic animals have been reported to be infected with Cryptosporidium spp. with varying prevalence rates $[9,156]$. There was evidence of zoonotic transmission of Cryptosporidium spp. between cattle and humans in northern New South Wales [157]. In the Northern Territory of Australia a more recent study reported in 2016 that water buffalo (Bubalus bubalis), showed a prevalence of $30 \%$ and $12 \%$ of Cryptosporidium spp. in farmed and wild buffaloes respectively. The species reported were $C$. parvum and C. bovis using an $18 \mathrm{~S}$ quantitative PCR (qPCR) and sequence analysis with C. parvum accounting for about $80 \%$ of infections in farmed buffaloes and 50\% in wild buffalo [158]. In southeastern Australia, a prevalence of $2.8 \%$ was reported for Cryptosporidium spp. from animals in water catchment areas with 14 unique sequence types for each of pSSU and pgp60, representing $C$. hominis, C. parvum, C. cuniculus and C. canis, C. fayeri, C. macropodum, and C. ubiquitum in addition to six new pSSU sequence types. Nothing appears to be known about the zoonotic potential of the 35 new genotypes recorded for the first time, of Cryptosporidium spp. and Giardia, which have been associated with Cryptosporidium spp. and this will require further studies [159]. The prevalence of the infection in sheep, using quantitative multiplex PCR, in 474 fecal samples from 2 sales yards on 4 occasions and 96 effluent samples, was $6.5 \%$ with the zoonotic species $C$. parvum and C. ubiquitum accounting for $54.2 \%$ of the positive samples [160].

\section{Treatment}

Effective treatment of cryptosporidiosis for humans and animals has eluded us for many years. Several drugs and drug combinations such as rifaximin, azithromycin, and paromomycin have been tried against cryptosporidiosis with unsatisfactory or inconsistent and reproducible results. So far the most promising of all anti-cryptosporidial agents, appears to be nitazoxanide, which has been approved for treatment of Cryptosporidiosis in humans by the U.S. FDA, but is not yet widely commercially available and awaits larger post marketing reports. Fortunately, most normal human hosts recover with nutritional and supportive therapy. However, cryptosporidiosis still remains a life threatening disease in immune compromised hosts.

\section{Prospects for control and eradication}

Controlling Cryptosporidium spp. infection is challenging because of the biological features of the parasites, their wide distribution in nature, and that oocysts may remain active in harsh environments and 
are resilient to common detergents [161]. Chlorine is commonly used in control of harmful microorganisms [162]. However, Cryptosporidium spp. are resistant to usual concentrations of $0.2-1 \mathrm{mg} / \mathrm{L}$ used in communal drinking water $[163,164]$. Sterilization processes using steam, ethylene oxide, Sterrad 100 (Johnson and Johnson, Norderstedt, Germany) and similar technologies can inactivate up to $3 \operatorname{logs}$ or more of C. parvum. However, the only liquid disinfectant/ sterilant that could do the same is $6 \%$ or $7.5 \%$ hydrogen peroxide. At lower concentrations or lower exposures, there is a lack of or incomplete inactivation. Other agents such as peracetic acid, sodium hypochlorite, a phenol, a quaternary ammonium compound, $2 \%$ glutaraldehyde, and orthophthalaldehyde did not completely inactive $3 \operatorname{logs}$ of C. parvum $[161,165]$, chlorine dioxide, ozone $\left(\mathrm{O}_{3}\right)$, or ultraviolet light have been used to disinfect drinking water, but this is not generally practical. The ability of Cryptosporidium oocysts to remain viable even after $10 \mathrm{~h}$ of immersion in glutaraldehyde is a serious cause for concern, especially in hospitals, because endoscopic equipment, which may come in contact with Cryptosporidium ssp., cannot be immersed for this long in glutaraldehyde to avoid corrosion [166].

Although water filtration may work, flocculation can clump the fine particulates found in water. Coagulators such as aluminum sulfate, iron (II) sulphate, or iron (III) chloride can be used to neutralize the negatively charged oocysts, thus promoting their coagulation. Sedimentation and filtration provided an effective barrier for Cryptosporidium spp. [162]. Instead of using ineffective chemical means of water purification and very difficult filtration processes, there is a new trend towards reverse osmosis, membrane filtration, and electronic/radiation methods [167, 168]. In childcare centers, cryptosporidiosis can be prevented by frequent disinfection using hydrogen peroxide or ammonia. Extra care needs to be taken when handling diapers and toys [161]. In the absence of any viable vaccine against cryptosporidiosis, proper hygiene is paramount for the control and prevention of infection.

\section{Conclusion}

Cryptosporidiosis is an emerging global zoonosis that is still poorly understood and largely neglected. Reports are often sporadic or nonexistent. However, there are now enough reliable reports to be concerned. The mechanisms by which Cryptosporidium spp. are able to adapt to several hosts and its ability to withstand many adverse conditions is still insufficiently understood and studied. There are no conclusive studies concerning transplacental transmission of oocysts in animals and man despite detection of oocysts in newborn animals. The threat posed by a parasite that is rapidly evolving and expanding its host range should not be underestimated; especially considering that there is still no specific effective therapeutic drug available to cure infection. C. parvum appears to be the most important Cryptosporidium sp. because of its widespread geographical distribution, the number of animal species affected, and its zoonotic potential. Equally common in humans is C. hominis. In the absence of vaccines; proper hygiene, and consumption of food and water free from Cryptosporidium oocysts appear to be the only method at present, to prevent infection with cryptosporidiosis.

\section{Acknowledgment}

The authors are grateful to the Faculty of Veterinary Medicine Universiti Malaysia Kelantan for providing support.

\section{Conflict of interest statement}

The authors declare that there is no conflict of interest in this research.

\section{References}

1. Aniesona AT, Bamaiyi PH. Retrospective study of cryptosporidiosis among diarrhoeic children in the arid region of north-eastern Nigeria. Zoonoses Public Health. 2014; 61:420-6.

2. Bamaiyi PH, Umoh JU, Abdu PA, Idris A. The prevalence of Cryptosporidium oocysts in birds in Zaria, Nigeria. Borneo J Resour Sci Technol. 2013; 2: 52-9.

3. Rossle NF, Latif B. Cryptosporidiosis as threatening health problem: a review. Asian Pac J Trop Biomed. 2013;3:916-24.

4. Wang Y, Yang W, Cama V, Wang L, Cabrera L, Ortega Y, et al. Population genetics of Cryptosporidium meleagridis in humans and birds: evidence for cross-species transmission. Int J Parasitol. 2014; 44: 515-21.

5. Inpankaew $\mathrm{T}$, Jiyipong $\mathrm{T}$, Wongpanit $\mathrm{K}$, Pinyopanuwat N, Chimnoi W, Kengradomkij C, et al. Molecular detection of Cryptosporidium spp. infections in water buffaloes from northeast Thailand. Trop Anim Health 
Prod. 2014; 46:487-90.

6. Sponseller JK, Griffiths JK, Tzipori S. The evolution of respiratory cryptosporidiosis: evidence for transmission by inhalation. Clin Microbiol Rev. 2014; 27:575-86.

7. Ryan U, Power M. Cryptosporidium species in Australian wildlife and domestic animals. Parasitology. 2012; 139:1673-88.

8. Ng J, Yang R, McCarthy S, Gordon C, Hijjawi N, Ryan U. Molecular characterization of Cryptosporidium and Giardia in pre-weaned calves in Western Australia and New South Wales. Vet Parasitol. 2011; 176:145-50

9. Ryan UNA, Fayer R, Xiao L. Cryptosporidium species in humans and animals: current understanding and research needs. Parasitology. 2014; 141:1667-85.

10. Bodager JR, Parsons MB, Wright PC, Rasambainarivo F, Roellig D, Xiao L, et al. Complex epidemiology and zoonotic potential for Cryptosporidium suis in rural Madagascar. Vet Parasitol. 2015; 207:140-3.

11. Wong SSY. The sick returned traveller. Top Updat Hong Kong Coll Pathol. 2016; 11:1-10.

12. Miller RA, Bronsdon MA, Morton WR. Experimental cryptosporidiosis in a primate model. J Infect Dis 1990; 161:312-5.

13. Aly I, Taher H, El-Feky F. Efficacy of low and high dose of paromomycin sulfate for treatment of cryptosporidiosis in immunosuppressed infected-mice. Glob Vet. 2015; 15:137-43.

14. Acikgoz Y, Ozkaya O, Bek K, Genc G, Sensoy SG, Hokelek M. Cryptosporidiosis: a rare and severe infection in a pediatric renal transplant recipient. Pediatr Transplant. 2012; 16:E115-9.

15. Savioli L, Smith H, Thompson A. Giardia and Cryptosporidium join the "neglected diseases initiative." Trends Parasitol. 2006; 22:203-8.

16. Fayer R. General Biology. In: Fayer R, Xiao L, editors. Cryptosporidium and cryptosporidiosis. 2nd ed., Boca Raton: CRC Press, Taylor and Francis Group; 2008, p.4-6.

17. Clarke JJ. Memoirs: A study of coccidia met with in mice. Q J Microsc Sci. 1895; s2-37:277-83.

18. Tyzzer EE. A sporozoan found in the peptic glands of the common mouse. Exp Biol Med. 1907; 5:12-3.

19. Maurya PS, Garg R, Banerjee PS, Kumar S, Rakesh RL, Kundu K, et al. Genotyping of Cryptosporidium species reveals prevalence of zoonotic C. parvum subtype in bovine calves of north India. Indian $\mathrm{J}$ Anim Sci. 2013; 83:1018-23.

20. Kurniawan A, Dwintasari SW, Connelly L, Nichols
RAB, Yunihastuti E, Karyadi T, et al. Cryptosporidium species from human immunodeficiency-infected patients with chronic diarrhea in Jakarta, Indonesia. Ann Epidemiol. 2013; 23:720-3.

21. Lim YAL, Jex AR, Smith H V, Gasser RB. Cryptosporidiosis in Southeast Asia: what's out there? Adv Parasitol. 2010; 71:1-31.

22. Ng-Hublin JSY, Hargrave D, Combs B, Ryan U. Investigation of a swimming pool-associated cryptosporidiosis outbreak in the Kimberley region of Western Australia. Epidemiol Infect. 2015; 143: 1037-41.

23. Fayer R, Santín M, Macarisin D. Cryptosporidium ubiquitum n. sp. in animals and humans. Vet Parasitol 2010; 172:23-32.

24. Jiang Y, Ren J, Yuan Z, Liu A, Zhao H, Liu H, et al. Cryptosporidium andersoni as a novel predominant Cryptosporidium species in outpatients with diarrhea in Jiangsu Province, China. BMC Infect Dis 2014; 14 : 555. doi:10.1186/s12879-014-0555-7.

25. Molina-Lopez RA, Ramis A, Martin-Vazquez S, Gomez-Couso H, Ares-Mazas E, Caccio SM, et al. Cryptosporidium baileyi infection associated with an outbreak of ocular and respiratory disease in otus owls (Otus scops) in a rehabilitation centre. Avian Pathol. 2010; 39:171-6.

26. Blagburn BL, Lindsay DS, Hoerr FJ, Davis JF, Giambrone JJ. Pathobiology of cryptosporidiosis $(C$. baileyi) in broiler chickens. J Protozool. 1991; 38:25S$8 \mathrm{~S}$.

27. Murakoshi F, Tozawa $\mathrm{Y}$, Inomata A, Horimoto T, Wada Y, Kato K. Molecular characterization of Cryptosporidium isolates from calves in Ishikari District, Hokkaido, Japan. J Vet Med Sci. 2013; 75: $837-40$.

28. Xu H, Jin Y, Wu W, Li P, Wang L, Li N, et al. Genotypes of Cryptosporidium spp., Enterocytozoon bieneusi and Giardia duodenalis in dogs and cats in Shanghai, China. Parasit Vectors. 2016; 9:121.

29. Koehler A V, Whipp MJ, Haydon SR, Gasser RB. Cryptosporidium cuniculus - new records in human and kangaroo in Australia. Parasit Vectors. 2014; 7: 492. doi: 10.1186/s13071-014-0492-8.

30. Puleston RL, Mallaghan CM, Modha DE, Hunter PR, Nguyen-Van-Tam JS, Regan CM, et al. The first recorded outbreak of cryptosporidiosis due to Cryptosporidium cuniculus (formerly rabbit genotype), following a water quality incident. J Water Health. 2014; 12:41-50.

31. Kváè M, Hofmannová L, Hlásková L, Kvìtoòová D, 
Vítovec J, McEvoy J, et al. Cryptosporidium erinacei n. sp. (Apicomplexa: Cryptosporidiidae) in hedgehogs. Vet Parasitol. 2014; 201:9-17.

32. Dowle M, Hill NJ, Power ML. Cryptosporidium from a free-ranging marsupial host: bandicoots in urban Australia. Vet Parasitol. 2013; 198:197-200.

33. Scorza V, Willmott A, Gunn-Moore D, Lappin MR. Cryptosporidium felis in faeces from cats in the UK. VetRec. 2014; 174:609.

34. Xiao S, An W, Chen Z, Zhang D, Yu J, Yang M. Occurrences and genotypes of Cryptosporidium oocysts in river network of southern-eastern China. Parasitol Res. 2012; 110:1701-9.

35. Chelladurai JJ, Clark ME, Kváè M, Holubová N, Khan E, Stenger BLS, et al. Cryptosporidium galli and novel Cryptosporidium avian genotype VI in North American red-winged blackbirds (Agelaius phoeniceus). Parasitol Res. 2016; 115:1901-6.

36. Widerström M, Schönning C, Lilja M, Lebbad M, Ljung T, Allestam G, et al. Large outbreak of Cryptosporidium hominis infection transmitted through the public water supply, Sweden. Emerg Infect Dis. 2014; 20:581-9.

37. Nolan MJ, Jex AR, Koehler A V., Haydon SR, Stevens MA, Gasser RB. Molecular-based investigation of Cryptosporidium and Giardia from animals in water catchments in southeastern Australia. Water Res. 2013;47:1726-40.

38. Baroudi D, Khelef D, Goucem R, Adjou KT, Adamu H, Zhang H, et al. Common occurrence of zoonotic pathogen Cryptosporidium meleagridis in broiler chickens and turkeys in Algeria. Vet Parasitol. 2013; 196:334-40.

39. Koinari M, Karl S, Ng-Hublin J, Lymbery AJ, Ryan UM. Identification of novel and zoonotic Cryptosporidium species in fish from Papua New Guinea. Vet Parasitol. 2013; 198:1-9.

40. Alvarez-Pellitero P, Sitjà-Bobadilla A. Cryptosporidium molnari n. sp. (Apicomplexa: Cryptosporidiidae) infecting two marine fish species, Sparus aurata L. and Dicentrarchus labrax L. Int J Parasitol. 2002; 32: 1007-21.

41. Tyzzer EE. An extracellular coccidium, Cryptosporidium muris (gen. et sp. nov.), of the gastric glands of the common mouse. J Med Res. 1910; 23:487.

42. DuPont HL, Chappell CL, Sterling CR, Okhuysen PC, Rose JB, Jakubowski W. The infectivity of Cryptosporidium parvum in healthy volunteers. N Engl J Med. 1995; 332:855-9.

43. Fayer R, Santín M, Trout JM. Cryptosporidium ryanae n. sp. (Apicomplexa: Cryptosporidiidae) in cattle (Bos taurus). Vet Parasitol. 2008; 156:191-8.

44. Kváè M, Kestøánová M, Pinková M, Kvìtoòová D, Kalinová J, Wagnerová $\mathrm{P}$, et al. Cryptosporidium scrofarum n. sp.(Apicomplexa: Cryptosporidiidae) in domestic pigs (Sus scrofa). Vet Parasitol. 2013; 191: 218-27.

45. Cranfield MR, Graczyk TK. Experimental infection of elaphid snakes with Cryptosporidium serpentis (Apicomplexa: Cryptosporidiidae). J Parasitol. 1994; 823-6.

46. Koudela B, Modry D. New species of Cryptosporidium (Apicomplexa: Cryptosporidiidae) from lizards. Folia Parasitol (Praha). 1998; 45:93-100.

47. Ryan UM, Monis P, Enemark HL, Sulaiman I, Samarasinghe B, Read C, et al. Cryptosporidium suis n. sp. (Apicomplexa: Cryptosporidiidae) in pigs (Sus scrofa). J Parasitol. 2004; 90:769-73.

48. Ren X, Zhao J, Zhang L, Ning C, Jian F, Wang R, et al. Cryptosporidium tyzzeri n. sp.(Apicomplexa: Cryptosporidiidae) in domestic mice (Mus musculus). Exp Parasitol. 2012; 130:274-81.

49. Fayer R, Santín M, Macarisin D. Cryptosporidium ubiquitum $\mathrm{n}$. sp. in animals and humans. Vet Parasitol. 2010; 172:23-32.

50. Pavlasek I, Ryan U. Cryptosporidium varanii takes precedence over C. saurophilum. Exp Parasitol. 2008; 118:434-7.

51. Elwin K, Hadfield SJ, Robinson G, Crouch ND, Chalmers RM. Cryptosporidium viatorum n. sp.(Apicomplexa: Cryptosporidiidae) among travellers returning to Great Britain from the Indian subcontinent, 2007-2011. Int J Parasitol. 2012; 42:675-82.

52. Vetterling JM, Jervis HR, Merrill TG, Sprinz H. Cryptosporidium wrairi sp. $\mathrm{n}$. from the guinea pig Cavia porcellus, with an emendation of the genus. J Protozool. 1971; 18:243-7.

53. Fayer R, Santín M. Cryptosporidium xiaoi n. sp. (Apicomplexa: Cryptosporidiidae) in sheep (Ovis aries). Vet Parasitol. 2009; 164:192-200.

54. Current WL, Garcia LS. Cryptosporidiosis. Clin Microbiol Rev. 1991; 4:325-58.

55. Dhillon AS, Thacker HL, Dietzel A V, Winterfield RW. Respiratory cryptosporidiosis in broiler chickens. Avian Dis. 1981; 747-51.

56. Sponseller JK, Griffiths JK, Tzipori S. The evolution of respiratory cryptosporidiosis: evidence for transmission by inhalation. Clin Microbiol Rev. 2014; 27:575-86.

57. Mac Kenzie WR, Hoxie NJ, Proctor ME, Gradus MS, 
Blair KA, Peterson DE, et al. A massive outbreak in Milwaukee of Cryptosporidium infection transmitted through the public water supply. N Engl J Med. 1994; 331:161-7.

58. Casman EA, Fischhoff B, Palmgren C, Small MJ, Wu F. An integrated risk model of a drinking-water-borne cryptosporidiosis outbreak. Risk Anal. 2000; 20: 495-512.

59. Leitch GJ, He Q. Cryptosporidiosis-an overview. J Biomed Res. 2012; 25:1-16.

60. Yoder JS, Beach MJ. Cryptosporidium surveillance and risk factors in the United States. Exp Parasitol. 2010; 124:31-9.

61. Ziegler PE, Wade SE, Schaaf SL, Stern DA, Nadareski CA, Mohammed HO. Prevalence of Cryptosporidium species in wildlife populations within a watershed landscape in southeastern New York State. Vet Parasitol. 2007; 147:176-84.

62. Goldstein ST, Juranek DD, Ravenholt O, Hightower AW, Martin DG, Mesnik JL, et al. Cryptosporidiosis: an outbreak associated with drinking water despite state-of-the-art water treatment. Ann Intern Med. 1996; 124:459-68.

63. Feng Y, Wang L, Duan L, Gomez-Puerta LA, Zhang L, Zhao X, et al. Extended outbreak of cryptosporidiosis in a pediatric hospital, China. Emerg Infect Dis. 2012; 18:312-4.

64. Banwat EB, Egah DZ, Audu ES, Onile BA, Datong PR. Cryptosporidium infection in undernourished children with HIV/AIDS in Jos, Nigeria. Ann Afr Med. 2004; 3:80-2.

65. Maikai BV, Baba-Onoja EBT, Elisha IA. Contamination of raw vegetables with Cryptosporidium oocysts in markets within Zaria metropolis, Kaduna State, Nigeria. Food Control. 2013; 31:45-8.

66. Sia Su GL, Mariano CMR, Matti NSA, Ramos GB. Assessing parasitic infestation of vegetables in selected markets in Metro Manila, Philippines. Asian Pacific J Trop Dis. 2012; 2:51-4.

67. Kanya DY, Samuel UU, Abdulkareem BO. Prevalence and socio-environmental predictors of cryptosporidiosis in Kebbi State, Nigeria. Am J Biosci Bioeng. 2015; 3:149-57.

68. Abu Samra N, Thompson PN, Jori F, Frean J, Poonsamy B, du Plessis D, et al. Genetic characterization of Cryptosporidium spp. in diarrhoeic children from four provinces in South Africa. Zoonoses Pub Health. 2013; 60:154-9.

69. Gatei W, Suputtamongkol Y, Waywa D, Ashford RW, Bailey JW, Greensill J, et al. Zoonotic species of
Cryptosporidium are as prevalent as the anthroponotic in HIV-infected patients in Thailand. Ann Trop Med Parasitol. 2002; 96:797-802.

70. Tiangtip R, Jongwutiwes S. Molecular analysis of Cryptosporidium species isolated from HIV-infected patients in Thailand. Trop Med Int Health. 2002; 7: 357-64.

71. Srisuphanunt M, Saksirisampant W, Karanis P. Prevalence and genotyping of Cryptosporidium isolated from HIV/AIDS patients in urban areas of Thailand. Ann Trop Med Parasitol. 2011; 105:463-8.

72. Menon BS, Abdullah S, Mahamud F, Morgan UM, Malik AS, Choo KE, et al. Low prevalence of Cryptosporidium parvum in hospitalized children in Kota Bharu, Malaysia. Southeast Asian J Trop Med Public Health. 2001; 32:319-22.

73. Iqbal A, Dixon BR, Surin J, Lim YAL. Molecular epidemiology of Cryptosporidium in HIV / AIDS patients in Malaysia. Trop Biomed. 2015; 32:310-22.

74. Lim YAL, Mahdy MAK, Surin J. Unravelling Cryptosporidium and Giardia in Southeast Asia. In: Lim YAL, Mahdy MAK, Surin J., editors. Parasites and their vectors. New York: Springer. 2013; p77-102.

75. Koompapong K, Sukthana Y. Seasonal variation and potential sources of Cryptosporidium contamination in surface waters of Chao Phraya River and Bang Pu nature reserve pier, Thailand. Southeast Asian J Trop Med Public Health. 2012; 43:832-40.

76. Kumar T, Onichandran S, Lim YAL, Sawangjaroen N, Ithoi I, Andiappan H, et al. Comparative study on waterborne parasites between Malaysia and Thailand: a new insight. Am J Trop Med Hyg. 2014; 90:682-9.

77. Rohela M, Lim YA, Jamaiah I, Khadijah PY, Laang ST, Nazri MHM, et al. Occurrence of Cryptosporidium oocysts in wrinkled hornbill and other birds in the Kuala Lumpur National Zoo. Southeast Asian J Trop Med Public Heal. 2005; 36(Suppl 4):34-40.

78. Graczyk TK, Cranfield MR, Fayer R, Anderson MS. Viability and infectivity of Cryptosporidium parvum oocysts are retained upon intestinal passage through a refractory avian host. Appl Environ Microbiol. 1996; 62:3234-7.

79. Maity SN, Rahman SS. Cryptosporidiosis in HIV infected and non-infected patients with diarrhoea in a teaching hospital Hyderabad, India. Int J Curr Microbiol Appl Sci. 2015; 4:454-9.

80. Dey A, Ghoshal U, Agarwal V, Ghoshal UC. Genotyping of Cryptosporidium species and their clinical manifestations in patients with renal transplantation and human immunodeficiency virus infection. J Pathog. 
2016; 2016:2623602. doi: 10.1155/2016/2623602.

81. Ehsan AM, Geurden T, Casaert S, Parvin SM, Islam TM, Ahmed UM, et al. Assessment of zoonotic transmission of Giardia and Cryptosporidium between cattle and humans in rural villages in Bangladesh. PLoS One. 2015; 10:1-11.

82. Monge R, Chinchilla M. Presence of Cryptosporidium oocysts in fresh vegetables. J Food Prot. 1996; 59: 202-3.

83. Fayer R. Effect of high temperature on infectivity of Cryptosporidium parvum oocysts in water time ( $\mathrm{min}$ ). 1994; 60:2732-5.

84. Gallaher MM, Herndon JL, Nims LJ, Sterling CR, Grabowski DJ, Hull HF. Cryptosporidiosis and surface water. Am J Public Health. 1989; 79:39-42.

85. Checkley W, White AC, Jaganath D, Arrowood MJ, Chalmers RM, Chen X-M, et al. A review of the global burden, novel diagnostics, therapeutics, and vaccine targets for cryptosporidium. Lancet Infect Dis. 2015; 15:85-94.

86. Benjamin N, Uchechukwu C, Ikechukwu D, Oliver A, Muodebe N. Cryptosporidiosis among children in some rural parts of Imo state, Nigeria. J Public Heal Epidemiol. 2013; 5:440-4.

87. Tellevik MG, Moyo SJ, Blomberg B, Hjøllo T, Maselle SY, Langeland N, et al. Prevalence of Cryptosporidium parvum/hominis, Entamoeba histolytica and Giardia lamblia among young children with and without diarrhea in Dares Salaam, Tanzania. PLoS Negl Trop Dis. 2015; 9:e0004125.

88. Agnew DG, Lima AA, Newman RD, Wuhib T, Moore RD, Guerrant RL, et al. Cryptosporidiosis in northeastern Brazilian children: association with increased diarrhea morbidity. J Infect Dis. 1998; 177: $754-60$.

89. Newman R, Sears C. Longitudinal study of Cryptosporidium infection in children in northeastern Brazil. J Infect Dis. 1999; 180:167-75.

90. European Centre for Disease Prevention and Control. Increased Cryptosporidium infections in the Netherlands, United Kingdom and Germany in 2012. WHO Reg Off Eur 2012: 1-7. [online] 2012 [cited 2015 December 27] Available from: http://ecdc.europa.eu/ en/publications/Publications/cryptosporidiuminfectionss-netherlands-united-kingdom-germanyrisk-assessment.pdf

91. Cardona GA, Carabin H, Goñi P, Arriola L, Robinson G, Fernández-Crespo JC, et al. Identification and molecular characterization of Cryptosporidium and Giardia in children and cattle populations from the province of Álava, North of Spain. Sci Total Environ. 2011;412-413:101-8.

92. Ashbolt RH, Coleman DJ, Misrachi A, Conti JM, Kirk MD. An outbreak of cryptosporidiosis associated with an animal nursery at a regional fair. Commun Dis Intell. 2003; 27:244-9.

93. Waldron LS, Ferrari BC, Cheung-Kwok-Sang C, Beggs PJ, Stephens N, Power ML. Molecular epidemiology and spatial distribution of a waterborne cryptosporidiosis outbreak in Australia. Appl Environ Microbiol. 2011; 77:7766-71.

94. Lal A, Cornish LM, Fearnley E, Glass K, Kirk M. Cryptosporidiosis: a disease of tropical and remote areas in Australia. PLoS Negl Trop Dis 2015; 9: e0004078.

95. Santin M. Clinical and subclinical infections with Cryptosporidium in animals. NZ Vet J. 2013; 61:1-10.

96. Sweeny JPA, Ryan UM, Robertson ID, Jacobson C. Cryptosporidium and Giardia associated with reduced lamb carcase productivity. Vet Parasitol. 2011; 182:127-39.

97. Amer S, Zidan S, Feng Y, Adamu H, Li N, Xiao L. Identity and public health potential of Cryptosporidium spp. in water buffalo calves in Egypt. Vet Parasitol. 2013; 191:123-7.

98. Parsons MB, Travis D, Lonsdorf EV, Lipende I, Roellig DMA, Kamenya S, et al. Epidemiology and molecular characterization of Cryptosporidium spp. in humans, wild primates, and domesticated animals in the Greater Gombe Ecosystem, Tanzania. PLoS Negl Trop Dis. 2015; 9:1-13.

99. Samra NA, Jori F, Xiao L, Rikhotso O, Thompson PN. Molecular characterization of Cryptosporidium species at the wildlife/livestock interface of the Kruger National Park, South Africa. Comp Immunol Microbiol Infect Dis. 2013; 36:295-302.

100. Julius OO, Ileigo IH, Ezemuel YS, Olayinka O, Edet AE, Tayo K, et al. Molecular characterisation of Cryptosporidium species from extensively managed cattle slaughtered in Abattoirs in Kaduna State, Nigeria. Adv Appl Sci Res. 2016; 7:17-22.

101. Akinkuotu O, Fagbemi O, Egbetade O, Jacobs E, Adeyanju J. Prevalence of cryptosporidium coproantigens in goats in Ogun, Southwest Nigeria. J Vet Adv. 2015; 5:1.

102. Khezri M, Khezri O. The prevalence of Cryptosporidium spp. in lambs and goat kids in Kurdistan, Iran. Vet World. 2013; 6:974-7.

103. Bahrami F, Sadraei J, Frozandeh M. Molecular characterization of Cryptosporidium spp. in wild rats 
of Tehran, Iran using 18s rRNA gene and PCR RFLP method. Jundishapur J Microbiol. 2012; 5:486-90.

104. Gharekhani J, Heidari H, Youssefi M. Prevalence of Cryptosporidium infection in sheep in Iran. Türkiye Parazitolojii Derg. 2014; 38:22-5.

105. Norhamizah AH, Julaida S, Slamah B, Saudah S, Rasidah AL. Cryptosporidiosis in a commercial dairy cattle farm in Malaysia. Malaysian J Vet Res. 2011; 2: 33-9.

106. do Couto MCM, Lima M de F, do Bomfim TCB. New Cryptosporidium parvum subtypes of IIa subfamily in dairy calves from Brazil. Acta Trop. 2014; 130: 117-22.

107. Del Coco VF, Córdoba MA, Basualdo JA. Cryptosporidium infection in calves from a rural area of Buenos Aires, Argentina. Vet Parasitol. 2008; 158: 31-5.

108. Yap NJ, Koehler A V, Ebner J, Tan TK, Lim YAL, Gasser RB. Molecular analysis of Cryptosporidium from cattle from five states of Peninsular Malaysia. Mol Cell Probes. 2016; 30:39-43.

109. Liu A, Zhang J, Zhao J, Zhao W, Wang R, Zhang L. The first report of Cryptosporidium andersoni in horses with diarrhea and multilocus subtype analysis. Parasit Vectors. 2015; 8:483. doi:10.1186/s13071-0151102-0.

110. Wang R, Jian F, Sun Y, Hu Q, Zhu J, Wang F, et al. Large-scale survey of Cryptosporidium spp. in chickens and Pekin ducks (Anas platyrhynchos) in Henan, China: prevalence and molecular characterization. Avian Path. 2010; 39:447-51.

111. Xiao L, Ryan UM. Molecular epidemiology. In: Fayer R, Xiao L, editors. Cryptosporidium and cryptosporidiosis. 2nd ed., Boca Raton: CRC Press; 2007, p. 119-71.

112. Yin J, Yuan Z, Shen Y, Zhang J, Jiang Y, Cao J. Molecular identification of Cryptosporidium spp. from animal sources in China. J Infect Dev Ctries. 2013; 7:1020-2.

113. Qi M, Cai J, Wang R, Li J, Jian F, Huang J, et al. Molecular characterization of Cryptosporidium spp. and Giardia duodenalis from yaks in the central western region of China. BMC Microbiol. 2015; 15: 1-7.

114. Mi R, Wang X, Huang Y, Zhou P, Liu Y, Chen Y, et al. Prevalence and molecular characterization of Cryptosporidium in goats across four provincial level areas in China. PLoS One. 2014; 9:1-7.

115. Bawm S, Kyi S, Lay KK, Htun LL, Myaing TT. Prevalence and associated risk factors of
Cryptosporidium and Giardia species in cattle within Mandalay Region, Myanmar. J Adv Parasitol. 2014; 1: 49-53.

116. Lim YAL, Ahmad RA, Smith H V. Current status and future trends in Cryptosporidium and Giardia epidemiology in Malaysia. J Water Health. 2008; 6: 239-54.

117. Paul S, Sharma DK, Boral R, Mishra AK, Nayakwadi S. Cryptosporidiosis in goats: a review. Adv Anim Vet Sci. 2014; 2:49-54.

118. Reddy YVP, Sivajothi S, Reddy BS. Case report Cryptosporiodiosis in a nellore doe associated with hydrocephalus foetus. J Adv Parasitol. 2014; 1:39-40.

119. Matos O, Alves M, Xiao L, Cama V, Antunes F. Cryptosporidium felis and C. meleagridis in persons with HIV, Portugal. Emerg Infect Dis. 2004; 10:2256-7.

120. Faubert GM, Litvinsky Y. Natural transmission of Cryptosporidium parvum between dams and calves on a dairy farm. J Parasitol. 2000; 86:495-500.

121. Kanyari PWN, Oyejide AO, Alak JIB, Anderson DL, Wilson ST, Srivastava K. Cryptosporidium parvum: experimental transplacental transmission in murine hosts. Isr J Vet Med. 2002; 57:70-5.

122. Maurya PS, Rakesh RL, Pradeep B, Kumar S, Kundu $\mathrm{K}$, Garg R, et al. Prevalence and risk factors associated with Cryptosporidium spp. infection in young domestic livestock in India. Trop Anim Health Prod. 2013; 45: 941-6.

123. Masood S, Maqbool A, Anjum AA, Rashid MI, Choudhary ZI. Prevalence of cryptosporidium oocysts in bovine at different livestock farms by conventional microscopic and molecular techniques. J Anim Plant Sci. 2013; 23:1588-94.

124. Nasir A, Avais M, Khan MS, Khan JA, Hameed S, Reichel MP. Treating Cryptosporidium parvum infection in calves. J Parasitol. 2013; 99:715-7.

125. Nasir A, Avais M, Khan M, Ahmad N. Prevalence of Cryptosporidium parvum infection in Lahore (Pakistan) and its association with diarrhea in dairy calves. Int $\mathbf{J}$ Agric Biol. 2009; 11:221-4.

126. Shafiq MAB, Maqbool A, Khan UJ, Lateef M, Ijaz M. Prevalence, water borne transmission and chemotherapy of cryptosporidiosis in small ruminants. Pak J Zool. 2015; 47:1715-21.

127. Abe N, Matsubara K. Molecular identification of Cryptosporidium isolates from exotic pet animals in Japan. Vet Parasitol. 2015; 209:254-7.

128. Murakoshi F, Ichikawa-Seki M, Aita J, Yaita S, Kinami A, Fujimoto K, et al. Molecular epidemiological analyses of Cryptosporidium parvum virus 1 (CSpV1), 
a symbiotic virus of Cryptosporidium parvum, in Japan. Virus Res. 2016; 211:69-72.

129. Jittapalapong S, Pinyopanuwat N, Chimnoi W, Siripanth C, Stich RW. Prevalence of Cryptosporidium among dairy cows in Thailand. Ann NY Acad Sci. 2006; 1081:328-35.

130. Inpankaew T, Jiyipong T, Wongpanit K, Pinyopanuwat N, Chimnoi W, Kengradomkij C, et al. Molecular detection of Cryptosporidium spp. infections in water buffaloes from northeast Thailand. Trop Anim Health Prod. 2014; 46:487-90.

131. Koompapong K, Mori H, Thammasonthijarern N, Prasertbun R, Pintong A, Popruk S, et al. Molecular identification of Cryptosporidium spp. in seagulls, pigeons, dogs, and cats in Thailand. Parasite. 2014; 21:52.

132. Sricharern $\mathrm{W}$, Inpankaew $\mathrm{T}$, Keawmongkol S, Supanam J, Stich RW, Jittapalapong S. Molecular detection and prevalence of Giardia duodenalis and Cryptosporidium spp. among long-tailed macaques (Macaca fascicularis) in Thailand. Infect GenetEvol. 2016; S1567-1348:30035-1.

133. Guven E, Avcioglu H, Balkaya I, Hayirli A, Kar S, Karaer Z. Prevalence of cryptosporidiosis and molecular characterization of Cryptosporidium spp. in calves in Erzurum [Erzurum yöresinde buzagilarda cryptosporidiosisin prevalansi ve Cryptosporidium türlerinin moleküler karekterizasyonu]. Kafkas Üniversitesi Vet Fakültesi Derg. 2013; 19:969-74. [in English, Turkish abstract]

134. Içen H, Arserim NB, $I^{\circ} i k N$, Özkan C, Kaya A. Prevalence of four enteropathogens with immunochromatographic rapid test in the feces of diarrheic calves in East and Southeast of Turkey. Pak Vet J. 2013; 33:496-9.

135. Arslan MÖ, Ekinci A. Determination of Cryptosporidium parvum subtypes in cattle in Kars province of Turkey. Kafkas Üniversitesi Vet Fakültesi Derg. 2012; 18:A221-6.

136. Aslan G, Bayram G, Otað F, Direkel S, Taylan ÖA, Ceber K, et al. Investigation of the presence of Cryptosporidium spp. in different water sources in Mersin province, Turkey. Mikrobiyol Bul. 2012; 46: 93-100.

137. Hussin AG, Khalaf JM, Ali HM. Detection of intestinal protozoa in camels and their breeders in Najef, Iraq. Res J Vet Pract. 2015; 3:53-7.

138. Bamaiyi PH, Kalu AU, Ali M. Haemoparasites of the trade camel (Camelus dromedarius) arriving for slaughter at Maiduguri, Borno State, Nigeria. Cont J Vet Sci. 2011; 5:18-21.
139. Bamaiyi PH, Kalu AU. Gastrointestinal parasites infection in one-humped camels (Camelus dromedarius) of Nigeria. VRF. 2011; 2:278-81.

140. Hale CR, Scallan E, Cronquist AB, Dunn J, Smith K, Robinson T, et al. Estimates of enteric illness attributable to contact with animals and their environments in the United States. Clin Infect Dis. 2012; 54(Suppl 5): S472-9.

141. Cope JR, Prosser A, Nowicki S, Roberts MW, Roberts JM, Scheer D, et al. Preventing community-wide transmission of Cryptosporidium: a proactive public health response to a swimming pool-associated outbreak-Auglaize County, Ohio, USA. Epidemiol Infect. 2015; 143:3459-67.

142. Kváè M, Hoøická A, Sak B, Prediger J, Salát J, Širmarová J, et al. Novel Cryptosporidium bat genotypes III and IV in bats from the USA and Czech Republic. Parasitol Res. 2015; 114:3917-21.

143. Dreelin EA, Ives RL, Molloy S, Rose JB. Cryptosporidium and Giardia in surface water: a case study from Michigan, USA to inform management of rural water systems. Int J Environ Res Public Health. 2014; 11:10480-503.

144. Stenger BLS, Clark ME, Kváè M, Khan E, Giddings $\mathrm{CW}$, Prediger J, et al. North American tree squirrels and ground squirrels with overlapping ranges host different Cryptosporidium species and genotypes. Infect Genet Evol. 2015; 36:287-93.

145. Daly RF, Hill NT. Characterizing the role of animal exposures in cryptosporidiosis and shiga toxin producing Escherichia coli infections: South Dakota, 2012. Zoonoses Public Health. 2016.

146. Muñoz AP, Mercado PR, Morales TG, Bravo OV, Raffo CE. Cryptosporidium spp., comparative diagnosis and geospatial distribution in diarrheic calves from dairy farms, Valdivia, Chile. Rev MVZ Córdoba. 2014; 19:3954-1.

147. Santín M, Trout JM, Vecino JAC, Dubey JP, Fayer R. Cryptosporidium, Giardia and Enterocytozoon bieneusi in cats from Bogota (Colombia) and genotyping of isolates. Vet Parasitol. 2006; 141:334-9.

148. Stensvold CR, Elwin K, Winiecka-Krusnell J, Chalmers RM, Xiao L, Lebbad M. Development and application of a gp60-based typing assay for Cryptosporidium viatorum. J Clin Microbiol. 2015; 53:1891-7.

149. Hooton T, Wener MH, Weiss NS, Gilman R. Etiologies and manifestations of persistent diarrhea in adults with HIV-1 infection: a case-control study in Lima, Peru. J Infect Dis. 2015; 191:11-9.

150. Araújo A, Reinhard KJ, Leles D, Sianto L, Iñiguez A, 
Fugassa M, et al. Paleoepidemiology of intestinal parasites and lice in pre-Columbian South America. Chungara, Revista de Antropologfa Chilena 2011; 43: 303-313.

151. Peralta RHS, Velásquez JN, Cunha F de S, Pantano ML, Sodré FC, Silva S da, et al. Genetic diversity of Cryptosporidium identified in clinical samples from cities in Brazil and Argentina. Mem Inst Oswaldo Cruz. 2016; 111:30-6.

152. Kostopoulou D, Casaert S, Tzanidakis N, van Doorn D, Demeler J, von Samson-Himmelstjerna G, et al. The occurrence and genetic characterization of Cryptosporidium and Giardia species in foals in Belgium, The Netherlands, Germany and Greece. Vet Parasitol. 2015; 211:170-4.

153. García-Presedo I, Pedraza-Díaz S, González-Warleta M, Mezo M, Gómez-Bautista M, Ortega-Mora LM, et al. The first report of Cryptosporidium bovis, C. ryanae and Giardia duodenalis sub-assemblage A-II in roe deer (Capreolus capreolus) in Spain. Vet Parasitol. 2013; 197:658-64.

154. Cacciò SM, de Waele V, Widmer G. Geographical segregation of Cryptosporidium parvum multilocus genotypes in Europe. Infect Genet Evol. 2015; 31: 245-9.

155. Manser M, Granlund M, Edwards H, Saez A, Petersen E, Evengard B, et al. Detection of Cryptosporidium and Giardia in clinical laboratories in Europe-a comparative study. Clin Microbiol Infect. 2014; 20 : 065-71.

156. Nolan MJ, Jex AR, Koehler A V., Haydon SR, Stevens MA, Gasser RB. Molecular-based investigation of Cryptosporidium and Giardia from animals in water catchments in southeastern Australia. Water Res. 2013; 47:1726-40.

157. Ng JSY, Eastwood K, Walker B, Durrheim DN, Massey PD, Porigneaux P, et al. Evidence of Cryptosporidium transmission between cattle and humans in northern New South Wales. Exp Parasitol. 2012; 130:437-41.

158. Zahedi A, Phasey J, Boland T, Ryan U. First report of Cryptosporidium species in farmed and wild buffalo from the Northern Territory, Australia. Parasitol Res 2016; 115:1349-53.

159. Nolan MJ, Jex AR, Koehler A V., Haydon SR, Stevens MA, Gasser RB. Molecular-based investigation of Cryptosporidium and Giardia from animals in water catchments in southeastern Australia. Water Res. 2013; 47:1726-40.

160. Yang R, Gardner GE, Ryan U, Jacobson C. Prevalence and pathogen load of Cryptosporidium and Giardia in sheep faeces collected from saleyards and in abattoir effluent in Western Australia. Small Rumin Res. 2015; 130:216-20.

161. Chako CZ, Tyler JW, Schultz LG, Chiguma L, Beerntsen BT. Cryptosporidiosis in people: it's not just about the cows. J Vet Intern Med. 2010; 24:37-43.

162. Semenza JC, Nichols G. Cryptosporidiosis surveillance and water-borne outbreaks in Europe. Eur Commun Dis Bull. 2007; 12:120-3.

163. World Health Organization. Chlorine in drinking-water background document for development of WHO Guidelines for drinking-water quality. Vol. 2. 2003. Geneva: WHO.

164. Allgood G, Quick R. Correspondence water filtration: a practical, effective solution for providing sustained access to safe drinking water in the developing world. Environ Sci Technol. 2009; 43:2008-9.

165. Barbee SL, Weber DJ, Sobsey MD, Rutala WA. Inactivation of Cryptosporidium parvum oocyst infectivity by disinfection and sterilization processes. Gastrointest Endosc. 1999; 49:605-11.

166. Wilson JA, Margolin AB. The efficacy of three common hospital liquid germicides to inactivate Cryptosporidium parvum oocysts. J Hosp Infect. 1999; 42:231-7.

167. Guerrant RL. Cryptosporidiosis: an emerging, highly infectious threat. Emerg Infect Dis. 1997; 3:51-7.

168. King B, Fanok S, Phillips R, Swaffer B, Monis P. Integrated Cryptosporidium assay to determine oocyst density, infectivity, and genotype for risk assessment of source and reuse water. Appl Environ Microbiol. 2015; 81:3471-81. 